UDC 541.13.544.65

\title{
THE INFLUENCE OF VARIOUS FACTORS ON ELECTROCHEMICAL REDUCTION OF THE BISMUTH IONS
}

\author{
V.A.Majidzade \\ M.Naglyev Institute of Catalysis and Inorganic Chemistry, NAS of Azerbaijan \\ vuska_80@mail.ru
}

Received 22.02.2018

\begin{abstract}
The electrochemical reduction of the bismuth ions has been investigated in the tartaric electrolyte. Kinetics and mechanism of the process and the effect of various factors on the electroreduction process of the bismuth ions have been studied according to cyclic and liner polarization curves drawn on the $\mathrm{Pt}$ electrodes. According to data, the value of effective activation energy has been calculated. The results of the calculation indicate that the electrochemical reduction process of the bismuth ions is accompanied by electrochemical polarization.
\end{abstract}

Keywords: electroreduction, polarization, bismuth ions, tartaric electrolyte.

Recently, the increasing interest in synthesis of thin films from various semiconductive materials for their application in many areas of technology has been observed: in solar cells, sensors, optical storage devices ets. [1-7].

Among other metallic sulfides bismuth sulfide $\left(\mathrm{Bi}_{2} \mathrm{~S}_{3}\right)$ is one of attractive materials that are widely used in Schottky diode [8], supercapacitor electrodes [9], solar cells [10], sensors [11], photodetectors [12], thermoelectrical devices [13] and photoanodes for photoelectrochemical solar cells. It is related to its width of energetic forbidden zone that has values from 1.25 to $1.70 \mathrm{eV}$, and it gives possibility to form effectively solar energy [14-18]. On the other hand, $\mathrm{Bi}_{2} \mathrm{~S}_{3}$ belongs to ecologically nonhazardous material.

In addition, at present, much attention is paid to the unique electrical, physical and chemical properties of bismuth. Thin bismuth films exhibit high magnetoresistance, thermoelectric efficiency and interesting quantum effects. They are used in electrochromic devices and for the formation of contacts on semiconductors. All this stimulates the search for new $\mathrm{Bi}$ (III) complexes and the development of electrolytes based on them to produce metallic bismuth with nanometric and submicron sizes [19,20].

To obtain thin films of semiconductor materials by the electrochemical method, the first step is to study the kinetics and mechanism of the electroreduction process of the components separately. Therefore, the aim of our work is to study the kinetics and mechanism of the elec- troreduction process of bismuth ions from a tartaric solution and to determine the range of potentials under which these ions are deposited.

In the references, there are a number of works about the study of the electroreduction of bismuth ions from various electrolytes [21-25].

According to the voltampermetric data [19], it has been found that the acceleration of the electroreduction process of the thiocarbamide complexes $\mathrm{Bi}$ (III) is observed in the solution on a polycrystalline bismuth electrode when thiocyanate ions $\left(10^{-4} \ldots 10^{-1} \mathrm{M}\right)$ are added into the solution. The role of the $\mathrm{NCS}^{-}$ion as an electron bridge with the formation of a transition state is considered: the electrode surface - the adsorbed particle - the reducing complex.

The effect of water activity on the mechanism and kinetics of the electroreduction of $\mathrm{Bi}(\mathrm{III})$ ions on a dropping mercury electrode (DME) in chlorates (VII) was studied in [21, 22] using voltampermetric and impedance methods. In the concentration range of $4-8 \mathrm{~mol} / \mathrm{dm}^{3}$, the values of transfer coefficients and standard rate constants increase significantly, whereas the activation energy values decrease that demonstrates an increase in reversibility of electroreduction of the $\mathrm{Bi}(\mathrm{III})$ ions. The nature of the rate constants varies depending on the potential points in the multistage electroreduction process of the $\mathrm{Bi}(\mathrm{III})$ ions. With increasing concentrations of chlorate(VII), the standard rate constants $\mathrm{k}_{\mathrm{s}}$ for all solutions affect catalytically on the electroreduction process of $\mathrm{Bi}(\mathrm{III})$. The mul- 
tistage process is confirmed by the non-linear function $\ln k_{f}=f(E)$.

The electroreduction of $\mathrm{Bi}(\mathrm{III})$ ions on a bismuth electrode from solutions containing nitric, sulfuric or perchloric acid was studied by cyclic voltampermetry [23]. It was concluded that the cathodic wave is related to the reduction of nitrate ions catalyzed by electrodeposited bismuth.

Thin bismuth films [24] have been obtained by an electrochemical method on $n$-GaAs (110). Bismuth films up to several hundred nanometers have a strong texture (018), however, thicker films are polycrystalline. The height of the energy barriers of $n$-GaAs (018)/Bi contacts is $0.62 \mathrm{eV}$, about $0.2 \mathrm{eV}$ lower than for electrodeposited bismuth films on GaAs (100).

In [25] bismuth is electrochemically deposited from trilonate solutions. The study of the kinetics of the process shows that electrodeposition is a catalytic electrode process following by a sequential first-order chemical reaction. It was found that the properties of the coatings depend on the structure of deposits. As the size of the grains decreases, the microhardness of the coatings increases.

\section{Experimental part}

Electrolyte for electroreduction of bismuth was prepared as follows: background so-

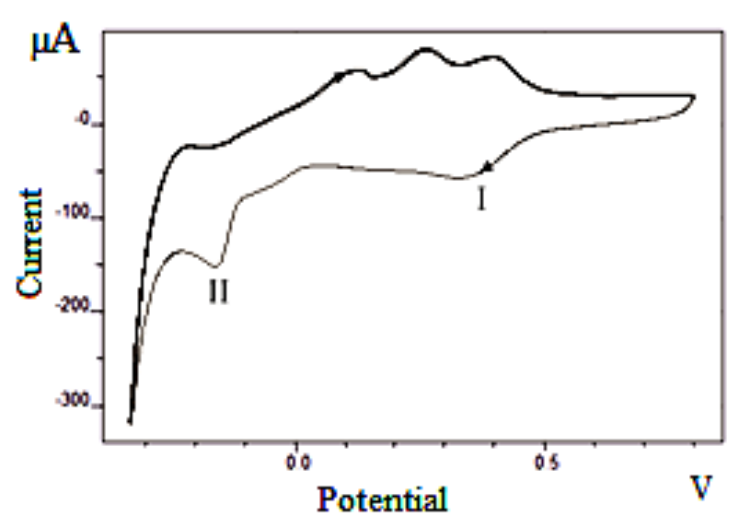

Fig. 1. The cyclic polarization curve of electroreduction of the bismuth ions from tartaric electrolyte. Electrolyte (M): $9 \cdot 10^{-4}$ $\mathrm{Bi}_{2} \mathrm{O}_{3}+7 \cdot 10^{-3} \mathrm{C}_{4} \mathrm{H}_{6} \mathrm{O}_{6} ; T=293 \mathrm{~K}, E_{\mathrm{V}}=$ $0.02 \mathrm{~V} / \mathrm{s}$. lution is prepared dissolving tartaric acid in water. Then $\mathrm{Bi}_{2} \mathrm{O}_{3}$ ("p.f.a.") was dissolved in the background solution. The electrolyte had the following composition: $\left(9 \cdot 10^{-5}-1.3 \cdot 10^{-3}\right) \mathrm{M} \mathrm{Bi}_{2} \mathrm{O}_{3}+$ $0.007 \mathrm{M} \mathrm{C}_{4} \mathrm{H}_{6} \mathrm{O}_{6}$.

The polarization curves were drawn in the potentiostat IVIUMSTAT Electrochemical Interface. An electrochemical triode cell with a capacity of $100 \mathrm{ml}$ was used. The working electrode was Pt with an area of $0.22 \mathrm{~cm}^{2}$. The reference electrode was a silver chloride electrode, and the auxiliary electrode was a platinum plate with an area of $4 \mathrm{~cm}^{2}$. The universal ultratermostat UTU-4 was used to regulate the temperature within cell.

\section{Results and discussion}

The kinetics and mechanism of the electrochemical reduction process of the bismuth ions, the influence of various factors on this process are studied by a potentiodynamic method in tartaric electrolyte.

As is seen from Figure 1, the electrochemical reduction of bismuth ions on the Pt electrode occurs in two stages within a potential range of $0.5-(-0.35) \mathrm{V}$. In our opinion, the electrochemical reduction of bismuth ions proceeds according to scheme below:

$$
\mathrm{Bi}(\mathrm{III}) \rightarrow \mathrm{Bi}(\mathrm{I}) \rightarrow \mathrm{Bi}(0) .
$$

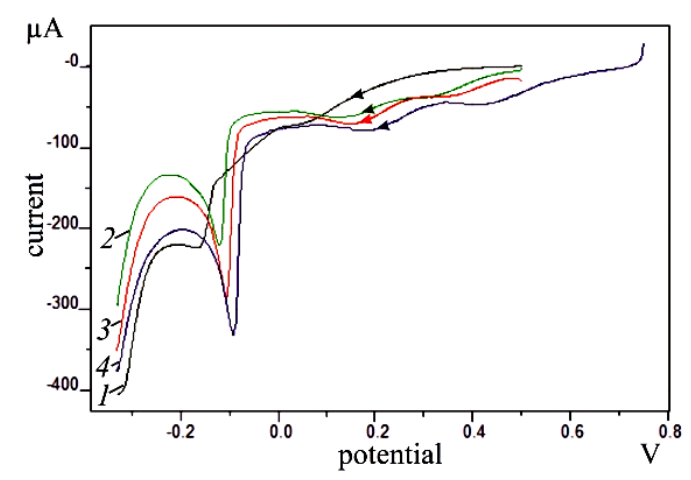

Fig. 2. The effect of temperature on the electroreduction process of the bismuth ions on the Pt electrode, K: $1-293,2-313,3-$ $333,4-353$. Electrolyte (M): $9 \cdot 10^{-4} \mathrm{Bi}_{2} \mathrm{O}_{3}$ $+7 \cdot 10^{-3} \mathrm{C}_{4} \mathrm{H}_{6} \mathrm{O}_{6} ; E_{\mathrm{V}}=0.02 \mathrm{~V} / \mathrm{s}$. 
Then, the kinetics of the electroreduction process was studied with using the temperaturekinetic method of Gorbachev [26]. For this, the influence of the temperature was studied by the potentiodynamic method within the 293-353 K intervals (Figure 2). The results show that as the temperature of the electrolyte increases, the electroreduction potential of the bismuth ions slides to the positive side.

As is seen from Figure 2, the beginning of the reduction at $293 \mathrm{~K}$ occurs at $-0.15 \mathrm{~V}$, and for the $353 \mathrm{~K}$ temperature at $0.05 \mathrm{~V}$ potential. Using these polarization curves, the function between $\lg i_{\mathrm{k}}$ and $1 / T$ was constructed (Figure 3 ).

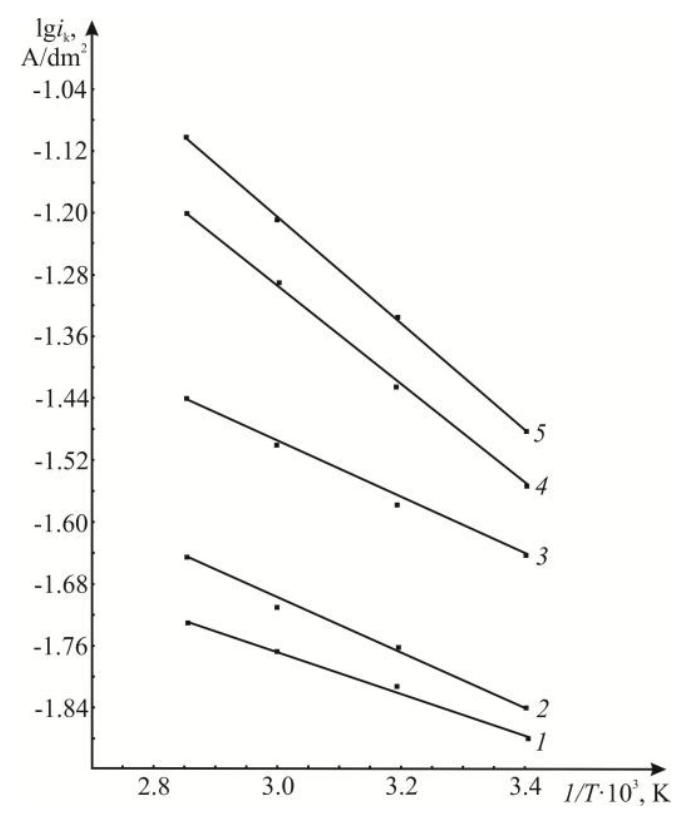

Fig. 3. The function between $\lg i_{\mathrm{k}}$ and $1 / T$ at various potentials $E(\mathrm{~V}): 1-(-0.03)$, $2-(-0.05), 3-(-0.075), 4-(-0.1), 5-$ $(-0.12)$.

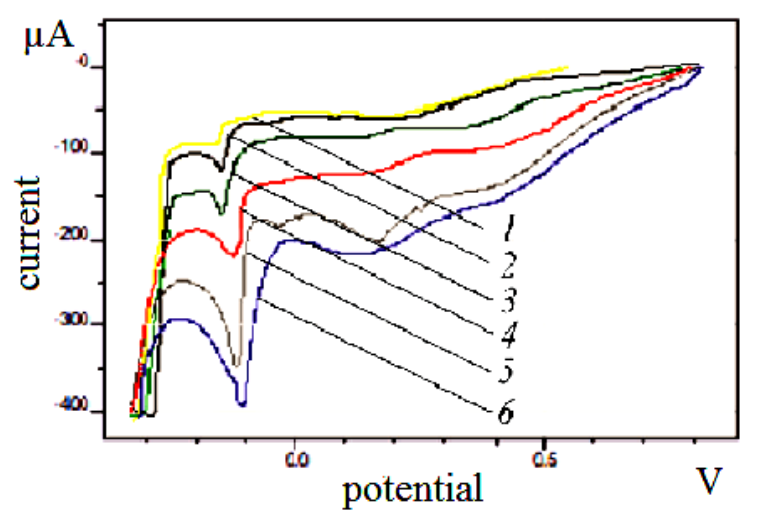

From the obtained straight lines shown in Figure $3 \operatorname{tg} \alpha$ is calculated. The value of the effective activation energy obtained by the equation $A_{\text {eff }}=-2.3 \operatorname{Rtg} \alpha$ shows that the electrochemical reduction of bismuth ions from tartaric electrolytes is accompanied by electrochemical polarization (Figure 4).

The influence of various factors on the electroreduction of bismuth ions from tartaric electrolytes has also been studied. At first, the effect of the concentration of bismuth ions on the electrochemical reduction process was studied (Figure 5).

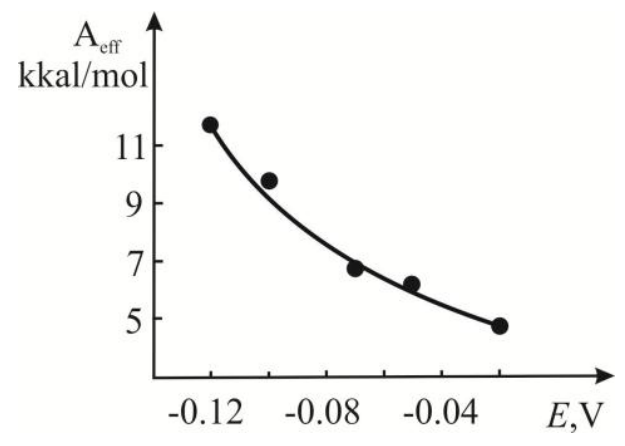

Fig. 4. The effective activation energy as a function of catodic potential.
Fig. 5. The effect of the concentration of bismuth ions on the electrochemical reduction process on the $\mathrm{Pt}$ electrode. Electrolyte (M): $1-9 \cdot 10^{-5}, 2-2.2 \cdot 10^{-4}, 3-3.4 \cdot 10^{-4}, 4-5.6 \cdot 10^{-4}$, $5-9 \cdot 10^{-4}, 6-1.3 \cdot 10^{-3} \mathrm{Bi}_{2} \mathrm{O}_{3}+7 \cdot 10^{-3} \mathrm{C}_{4} \mathrm{H}_{6} \mathrm{O}_{6}$; $E_{\mathrm{V}}=0.02 \mathrm{~V} / \mathrm{s} . T=293 \mathrm{~K}$. 
As can be seen from Figure 5, the polarization curves of the electroreduction process of the bismuth ions, with increasing its concentration in solution slide to the positive side from -0.125 to $0.0 \mathrm{~V}$. In addition, the change of the concentration of the bismuth ions in the electrolyte affects the rising of the current spent for the process.

The influence of the scanrate on the electroreduction process of the bismuth ions on the Pt electrode has been also studied.

Figure 6 shows the polarization curves drawn in a linear way. As can be seen, with
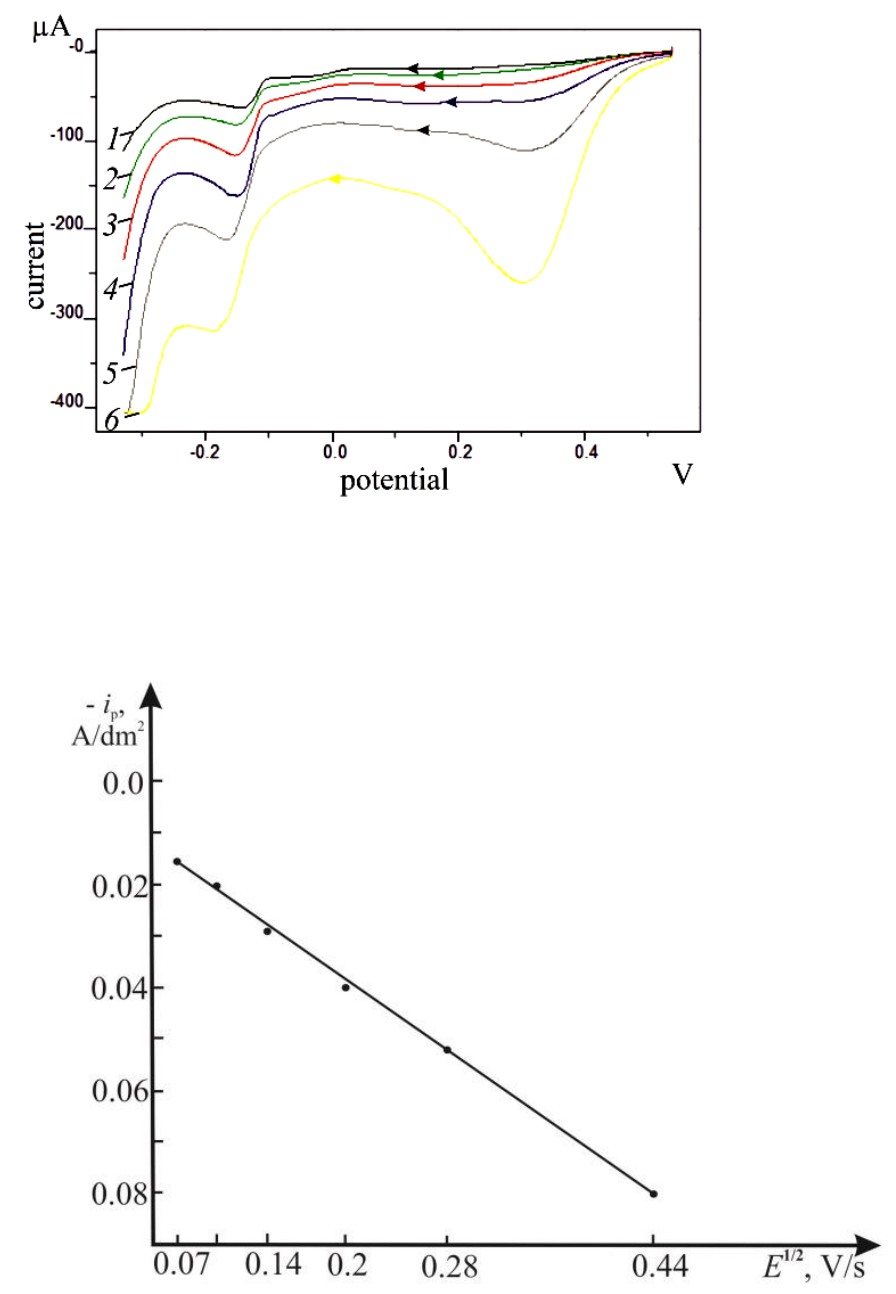

increasing of the scanrate the rising of the current of the electroreduction process is observed. Since, current at $0.005 \mathrm{~V} / \mathrm{s}$ is $-1.052 \cdot 10^{-4} \mathrm{~A}$, and at $0.2 \mathrm{~V} / \mathrm{sis}-4.064 \cdot 10^{-4} \mathrm{~A}$.

From explaining the kinetics and mechanism of the process of electroreduction of bismuth ions, a relationship is also constructed between $i_{\mathrm{p}}-E^{1 / 2}$ (Figure 7). As can be seen there is a straight line relationship between them. That is, as the scanrate increases, $i_{\mathrm{p}}$ also increases. This also proves that the electroreduction process is accompanied by electrochemical polarization.

Fig. 6. The influence of the scanrate on the electroreduction process of the bismuth ions on the $\mathrm{Pt}$ substrates. Electrolyte $(\mathrm{M})$ : $9 \cdot 10^{-4} \mathrm{Bi}_{2} \mathrm{O}_{3}+7 \cdot 10^{-3} \mathrm{C}_{4} \mathrm{H}_{6} \mathrm{O}_{6} ; T=293 \mathrm{~K}$, potential sweep (V/s.): $1-0.005,2-0.01$, $3-0.02,4-0.04,5-0.08,6-0.2$.

Fig. 7. The cathodic peak current density as a function of the square root of the scanrate. 


\section{Conclusion}

Electrochemical reduction of the bismuth ions on Pt electrodes in tartaric electrolytes was studied by the voltampermetric method of polarization. During the study of kinetics and mechanisms, it was revealed that the polarization would be accompanied by electrochemical kinetics. That is to say, the effective activation energy decreases with sliding of potential to positive side in the limiting stage.

The results of all the done experiments show that the concentration of bismuth ions, the temperature, and the scanrate affect on the electroreduction process of the bismuth ions from tartaric electrolyte. Thanks to the experimental studies, the optimal regime and composition of the electrolyte for the electroreduction process of bismuth ions were selected. Electrolyte: $9 \cdot 10^{-}$ ${ }^{4} \mathrm{M} \mathrm{Bi}_{2} \mathrm{O}_{3}+7 \cdot 10^{-3} \mathrm{M} \mathrm{C}_{4} \mathrm{H}_{6} \mathrm{O}_{6}$, the electroreduction mode is $T=293 \mathrm{~K}$, the scanrate is $0.02 \mathrm{~V} / \mathrm{s}$.

\section{References}

1. Heini Saloniemi. Electrodeposition of $\mathrm{PbS}, \mathrm{PbSe}$ and PbTe thin films. Technical Research Center of Finland. VTT Publications. 2000. 83 p.

2. Tuyen Ngo T., Sudam Chavhan, Ivet Kosta, Oscar Miguel, Hans-Jurgen Grande, Ramón TenaZaera. Electrodeposition of Antimony Selenide Thin Films and Application in Semiconductor Sensitized Solar Cells // ACS Appl. Mater. Interfaces. 2014. V. 6. No 4. P. 2836-2841.

3. Wooju Lee, Seonghan Jeong, Noseung Myung, Krishnan Rajeshwar, Chi-Woo Lee. Compositional Analysis of Electrodeposited $\mathrm{Cu}-\mathrm{Se}$ Compound Semiconductor Thin Films Using Combined Voltammetry and Flow-Electrochemical Quartz Crystal Microgravimetry // Bull. Korean Chem. Soc. 2013. V. 34. No 10. P. 3113-3116.

4. Waters J., Gouch D., O’Brein P., Park J.H. Fabrication of thin films of bismuth selenide using novel single-source precursors by metal organic chemical vapor deposition // J. Mater. Sci. Mater. Electron. 2003. V. 14. No 9. P. 599-602.

5. Ghosh S.K., Srivastava C., Nath S., Celis J.P. Simple Formation of Nanostructured Molybdenum Disulfide Thin Films by Electrodeposition // Int. J. of Electrochem. 2013. V. 2013. Article ID 138419. 7 p. http://dx.doi.org/10.1155/2013/138419.

6. Mahmoud El-rouby, Akif Shikhan Aliyev. Electrical, electrochemical and photo-electrochemical studies on the electrodeposited n-type semiconductor hexagonal crystalline $\mathrm{CdS}$ thin film on nickel substrate // J. Mater. Sci.: Mater. in Electronics. 2014. V. 25. No 12. P. 5618-5629.

7. Takashi Ohmori, Raúl J. Castro, Carlos R. Cabrera. In Situ Study of Silver Electrodeposition at $\mathrm{MoSe}_{2}$ by Electrochemical Scanning Tunneling Microscopy // Langmuir. 1998. V. 14. No 23. P. 6755-6760.

8. Bao H.,. Li C.M, Cui X., Gan Y., Song Q., Guo J. Synthesis of a Highly Ordered Single-Crystalline $\mathrm{Bi}_{2} \mathrm{~S}_{3}$ Nanowire Array and its Metal/Semiconductor/Metal Back-to-Back Schottky Diode // Small. 2008. No 4. P.1125-1129.

9. Ma L., Zhao Q., Zhang Q., Ding M., Huang J., Liu X., Liu Y., Wu X., Xu X. Controlled assembly of $\mathrm{Bi}_{2} \mathrm{~S}_{3}$ architectures as Schottky diode, supercapacitor electrodes and highly efficient photocatalysts // RSC Adv. 2014. No 4. P. 41636-41641.

10. Cao Y., Bernechea M., Maclachlan A., Zardetto V., Creatore M., Haque S.A., Konstantatos G. Solution Processed Bismuth Sulfide Nanowire Array Core/Silver Sulfide Shell Solar Cells //Chem. Mater. DOI 10.1021/acs.chem.mater.5b00783(2015) 150508094841005.

11. Yao K., Gong W.W., Hu Y.F., Liang X.L., Chen Q., Peng L.M. Individual $\mathrm{Bi}_{2} \mathrm{~S}_{3}$ Nanowire-Based Room-Temperature $\mathrm{H}_{2}$ Sensor // J. Phys. Chem. C. 2008. V.112. P. 8721-8724.

12. Konstantatos G., Levina L., Tang J., Sargent E.H. Sensitive Solution-Processed $\mathrm{Bi}_{2} \mathrm{~S}_{3}$ Nanocrystalline Photodetectors // Nano Letters. 2008. No 8. P. 4002-4006.

13. Yang Q., Hu C., Wang S., Xi Y., Zhang K. Tunable Synthesis and Thermoelectric Property of $\mathrm{Bi}_{2} \mathrm{~S}_{3}$ Nanowires // J. Phys. Chem. C. 2013. V. 117. P. 5515-5520.

14. Lu J., Han Q., Yang X., Lu L., Wang X. Microwave-assisted synthesis and characterization of 3D flower-like $\mathrm{Bi}_{2} \mathrm{~S}_{3}$ superstructures // Mater Lett. 2007. No 6. P. 2883-2886.

15. Rincón M.E., Hu H., Martínez G., Suárez R., Bañuelos J.G. Inclusion of $\mathrm{Bi}_{2} \mathrm{~S}_{3}$ nanoparticles in polypyrrole thin films electropolymerized on chemically deposited bismuth sulfide electrodes: synthesis and characterization // Sol. Energy Mater. Sol Cells. 2003. V. 77. P. 239-254.

16. Li Q., Shao M.W., Wu J., Guihua Yu., Yitai Qian. Synthesis of nano-fibrillary bismuth sulfide by a surfactant-assisted approach // Inorg. Chem. Commun. 2002. V. 5. P. 933-936.

17. Sirimanne P.M., Takahashi K., Sonoyama N., Sakata T. Photocurrent enhancement of wide bandgap $\mathrm{Bi}_{2} \mathrm{O}_{3}$ by $\mathrm{Bi}_{2} \mathrm{~S}_{3}$ over layers // Sol. Energy Mater. Sol. Cells. 2002. V. 73. P.175-187.

18. Lin Z.C., Eads C.D. Polymer-Induced Structural Transitions in Oleate Solutions: Microscopy, Rheology and Nuclear Magnetic Resonance Studies // Langmuir. 1997. V. 13. P. 2647- 2654. 
19. Petrova T.P., Starodubech Y.Y., Adyukova N.N., Shapnik A.M. Electroreduction of complex ions of bismuth (III) from aqueous solutions containing thiocarbamide thiocyanate ions // Wordbook of Cazan Technological University. 2010. No 6. P. 145-150.

20. Petrova T.P., Shapnik A.M., Rahmatullina I.F. Kinetics of electroreduction of bismuth (III) ions from acidic perchloric solution containing thiocyanate ions // Wordbook of Cazan Technological University. 2006. No 4. P. 130-136.

21. Agnieszka Nosal-Wiercińska. The kinetics and mechanism of the electroreduction of $\mathrm{Bi}(\mathrm{III})$ ions from chlorates (VII) with varied water activity // Electrochemical Acta. 2010. V. 55. No 20. P. 5917-5921.

22. Agnieszka Nosal-Wiercińska, Mariusz Grochowski, Małgorzata Wiśniewska, Katarzyna TyszczukRotko, Sławomira Skrzypek, Mariola Brycht, Dariusz Guziejewski. The Influence of Protonation on the Electroreduction of Bi (III) Ions in Chlorates(VII) Solutions of Different Water Activity // Electrocatalysis. 2015. V. 6. No 3. P. 315-321.

23. Petrova T.P., Shapnik A.M., Rahmatullina I.F. Electrodeposition of bismuth from acidic solutions // // Wordbook of Cazan Technological University. 2012. V. 15. No 21. P. 49-52.

24. Philippe M. Vereecken, Kenneth Rodbell, Chunxin $\mathrm{Ji}$, Peter C. Searson. Electrodeposition of bismuth thin films on n-GaAs (110) // Appl. Physics Lett. 2005. V. 86. P. 1219161-3.

25. Yermankova N.A. Electrodeposition and structure of bismuth and and its alloys obtained from trilonate solutions. Avtoref.... kand. him. nauk. Tiumen, Tiumensk. gos. un-t. 1984. 179 p.

26. Gorbachov S.B. The effect of temperature on the rate of electrolysis // J. Phys. chem. 1950. V. 24. No 7. P. 888-896.

\title{
BİSMUT İONLARININ ELEKTROKIMYəVİ REDUKSIYA PROSESINO MÜXTəLIF FAKTORLARIN TOSIRI
}

\begin{abstract}
V.A.Məcidzado
Təqdim olunan tədqiqat işində çaxir turşusu elektrolitlərindən bismut ionlarının elektrokimyəvi reduksiya prosesi tədqiq edilmişdir. Polyarizasiya əyrilərinin çəkilməsi ilə Pt-elektrodu üzərində bismut ionlarının elektroreduksiya prosesinin kinetika və mexanizmi, həmçinin müxtəlif amillərin prosesə təsiri öyrənilmişdir. Oldə edilən nəticələrə əsasən elektrokimyəvi reduksiya prosesinin effektiv aktivləşmə enerjisi hesablanmışdır. Hesablamalar göstərir ki, tartrat məhlullarından bismut ionlarının elektroreduksiyası elektrokimyəvi polyarizasiya ilə müşayiət olunur.
\end{abstract}

Açar sözlari: elektroreduksiya, polyarizasiya, bismut ionları, çaxir turşusu elektroliti.

\section{ВЛИЯНИЕ РАЗЛИЧНЫХ ФАКТОРОВ НА ЭЛЕКТРОХИМИЧЕСКОЕ ВОССТАНОВЛЕНИЕ ИОНОВ ВИСМУТА}

\section{В.А.Меджидзаде}

Исследовано электрохимическое восстановление ионов висмута из виннокислого электролита. Снятием циклических и линейных поляризационных кривых на Рt-электродах изучена кинетика, механизм процесса и влияние различных факторов на электровосстановление ионов висмута. По полученным данным рассчитана эффективная энергия активации. Результаты вычисления показывают, что процесс электровосстановления ионов висмута из тартратных растворов сопровождается электрохимической поляризацией.

Ключевые слова: электровосстановление, поляризаџия, ионы висмута, виннокисльй электролит. 